\title{
HUBUNGAN ANTARA PENGUASAAN TEORI DASAR-DASAR ELEKTRONIKA DENGAN PENGUASAAN PENGUKURAN KOMPONEN ELEKTRONIKA DALAM MENINGKATKAN HASIL BELAJAR PADA MATERI MEMAHAMI DASAR- DASAR ELEKTRONIKA SISWA KELAS X SMKN 1 GENENG
}

\author{
Ina Sunaryantiningsih ${ }^{1}$, Dedi Kurniawan ${ }^{2}$ \\ ${ }^{1}$ Prodi Pendidikan Teknik Elektro, FPTK, IKIP PGRI Madiun \\ Madiun, 63118, Indonesia \\ ${ }^{2}$ Prodi Pendidikan Teknik Elektro, FPTK, IKIP PGRI Madiun \\ Madiun, 63118, Indonesia \\ Email : inasmerdeka@ikippgrimadiun.ac.id; dedipte@gmail.com
}

\begin{abstract}
ABSTRAK
Pendidikan nasional berfungsi untuk mengembangkan kemampuan dan membentuk watak serta karakter bangsa dalam peradaban bangsa yang bermartabat dalam rangka mencedaskan kehidupan anak bangsa, berdasarkan fungsi pendidikan nasional ini maka peranan guru menjadi kunci keberhasilan dalam misi pandidikan dalam pembelajaran di sekolah. Tujuan dari penelitian ini adalah untuk mengetahui ada atau tidaknya hubungan antara metode penguasaan teori dasar-dasar elektronika dengan metode penguasaan pengukuran komponen elektronika dalam meningkatkan prestasi belajarsiswa pada mata pelajaran memahami dasardasar elektronika. Rancangan penelitian yang digunakan adalah studi korelasi dengan jumlah populasi 65 siswa. Metode pengambilan sampel yang digunakan adalah sampel keseluruhan yaitu kelas X La dan X Lb di SMKN 1 Geneng. Instrumen pengambilan data dengan menggunakan metode tes. Dalam menganalisis data menggunakan teknik korelasi product moment dan uji signifikansi dengan rumus t-tes. Hasil perhitungan korelasi product moment (r) sebesar 0,852 dengan taraf kepercayaan 95\%. Hasil ini lebih besar dari $\mathrm{r}$ tabel korelasi yaitu sebesar 0,244 atau 0,852>0,244, ini berarti masuk kategori tinggi pada tabel interprestasi, karena masuk antara 0,800 sampai dengan 1,00. Sedangkan hasil perhitungan lainnya dengan uji signifikan t-tes dengan kesalahan $12 \%$ uji dua fihak diperoleh t tabel $=$ 1,782, ini berarti hasil perhitungan uji signifikan t-tes lebih besar dari dari harga t-tabel atau $12,827>1,782$. Dengan demikian penelitian ini dapat disimpulkan bahwa ada hubungan yang signifikan antara metode penguasaan teori dasar-dasar elektronika dangan metode penguasaan pengukuran komponen elektronika dalam meningkatkan prestasi belajar pada mata pelajaran dasar kompetensi kejuruan materi memahami dasar-dasar elektronika siswa kelas X SMKN 1 Geneng.
\end{abstract}

Kata kunci: Teori Dasar-dasar Elektronika, Pengukuran Komponen Elektronika, HasilBelajar

\section{Pendahuluan}

Pendidikan pada dasarnya merupakan proses untuk membantu manusia dalam mengembangkan dirinya sehingga mampu menghadapi setiap perubahan yang terjadi. Dalam Undang-undang sistem pendidikan nasional tahun 2003 (Bab I pasal 1) disebutkan bahwa: Pendidikan adalah usaha sadar dan terencana untuk mewujudkan suasana belajar dan proses pembelajaran agar peserta didik secara aktif mengembangkan potensi dirinya untuk memiliki kekuatan spiritual keagamaan, pengendalian diri, kepribadian, kecerdasan, akhlak mulia 
serta ketrampilan yang dimiliki dirinya masyarakat bangsa dan negara.

Dalam pendidikan formal, belajar menunjukkan adanya perubahan yang sifatnya positif sehingga pada tahap akhir akan didapat keterampilan, kecakapan dan pengetahuan baru. Hasil dari proses belajar tersebut tercermin dalam prestasi belajarnya. Namun dalam upaya meraih prestasi belajar yang memuaskan dibutuhkan proses belajar.

Proses belajar yang terjadi pada individu memang merupakan sesuatu yang penting. Karena melalui belajar, individu mengenal lingkungannya dan menyesuaikan diri dengan lingkungan disekitarnya. Menurut Slameto (2010: 2) belajar secara psikologis merupakan suatu proses perubahan tingkah laku sebagai hasil dari interaksi dengan lingkungannya dalam memenuhi kebutuhan hidupnya. Oleh karena itu dengan belajar, siswa diharapkan dapat mewujudkan cita-cita yang diharapkan.

Menyadari hal tersebut upaya untuk meningkatkan kualitas pendidikan terusmenerus dilakukan secara baik oleh pemerintah dengan menitik beratkan pengembangan pendidikan dan peningkatan mutu setiap jenjang dan setiap jenis pendidikan serta luas kesempatan belajar pada jenjang pendidikan tingkat atas. Hal ini menunjukkan Pemerintah menyadari bahwa keberhasilan pembangunan nasional ditunjang dari majunya Ilmu Pengetahuan dan Teknologi (IPTEK).

Seiring dengan majunya IPTEK dewasa ini, maka kebutuhan teknik elektro semakin meningkat. Tidak ada orang yang tidak memerlukan peralatan elektro dalam kehidupan sehari-hari, karena peralatan elektro dipandang begitu pentingnya.

Dasar-dasar elektronika dan pengukuran komponen elektronika merupakan standar kompetensi wajib untuk Sekolah Menengah Kejuruan pada kompetensi keahlian Teknik Instalasi Listrik. Dasar-dasar elektronika adalah salah satu teori dasar dari ilmu listrik dan merupakan salah satu mata pelajaran di bidang teknik yang paling banyak digunakan dalam penerapan nyata. Dasardasar elektronika menjelaskan tentang konsep dasar dari rangkaian elektronika, simbol-simbol komponen, sifat-sifat komponen dan karakteristik dari komponen elektronika.

Sedangkan pengukuran komponen elektronika merupakan kelanjutan dari pembelajaran pada standar kompetensi dasar-dasar elektronika. Siswa dalam melaksanakan standar kompetensi pengukuran komponen elektronika terlebih dahulu harus mempelajari teori dasar-dasar elektronika, dan hal itu praktek tidak bisa dilaksanakan. Sehingga bisa dikatakan bahwa kedua standar kompetensi tersebut saling berhubungan dan berkaitan erat.

Berdasarkan rumusan masalah diatas, maka penelitian ini bertujuan:

1. Untuk mengetahui prestasi siswa pada standar kompetensi teori dasar-dasar elektronika dan pengukuran komponen elektronika terhadap peningkatan prestasi belajar pada siswa kelas $\mathrm{X}$ teknik instalasi listrik SMKN I Geneng.

2. Untuk mengetahui ada tidaknya hubungan antara penguasaan teori dasar-dasar elektronika dengan penguasaan pengukuran komponen elektronika terhadap peningkatan prestasi belajar pada siswa kelas $\mathrm{X}$ teknik instalasi listrik SMKN I Geneng.

\section{Metode}

Penelitian ini dilakukan di SMKN I Geneng pada semester genap. Rancangan penelitian yang digunakan oleh peneliti adalah penelitian deskriptif kualitatif. Riyanto (2001: 23) menjelaskan penelitian deskriptif adalah penelitian yang diarahkan untuk memberi gejala-gajala, fakta-fakta atau kejadian-kajadian secara sistematis dan akurat, mengenai sifat-sifat populasi atau daerah tertentu. Dalam penelitian deskriptif cenderung tidak perlu mencari atau menerangkan saling hubungan dan menguji hipotesis. 
Dalam penelitian kualitatif analisis data merupakan kegiatan setelah data dari seluruh responden atau sumber data lain terkumpul. Kegiatan dalam analisis data adalah mengelompokkan data berdasarkan variabel dan jenis responden, mentabulasi data berdasarkan variabel dari seluruh responden, menyajikan data tiap variabel yang diteliti, melakukan perhitungan untuk menjawab rumusan masalah, dan melakukan perhitungan untuk menguji hipotesis yang telah diajukan.

Teknik analisis data dalam penelitian kualitatif menggunakan analisis statistik inferensial, sedangkan statistik inferensial adalah teknik statistik yang digunakan untuk populasi dalam mengolah atau menganalisis data. Teknik analisis data ini menggunakan korelasi product-moment untuk menentukan hubungan antara dua gejala interval yaitu teori dasar-dasar elektronika dan pengukuran komponen elektronika.

Dalam melakukan analisis data, peneliti menerangkan memakai korelasi product moment untuk mencari korelasi antara dua variabel yaitu antara variable $\mathrm{X}$ (nilai teori) dan Y (nilai praktek). Dengan mengunakan analisis korelasi product moment sekaligus dapat memberikan jawaban terhadap hipotesis,"hubungan antara penguasaan teori dasar-dasar elektronika dengan panguasaan pengukuran komponen elektronika terhadap peningkatan prestasi belajar pada siswa kelas X SMKN I Geneng”.

\section{Hasil Penelitian}

Berdasarkan perhitungan korelasi Product moment(r) diperoleh 0,852 apabila hasil perhitungan ini dikonsultasikan ke tabel harga kritik dari r, nilai kritikya pada $\mathrm{N}=65$ dengan taraf kepercayaan $95 \%$ terlihat nilai kritik menunjukkan 0,244 , ini berarti nilai hasil perhitungan analisis korelasi produt moment lebih besar dari nilai kritiknya, atau 0,852 >0,244. Selanjutnya hasil (r) 0,852 dikonsultasikan ke tabel interprestasi koefisien korelasi berada dalam kategori tinggi, karena masuk antara 0,800 sampai dengan 1,00. Jadi terdapat hubungan antara peenguasaan teori dasar-dasar elektronika dengan penguasaan pengukuran komponen elektronika di SMKN 1 Geneng.

Harga $\mathrm{t}$ hitung tersebut selanjutnya dibandingkan dengan harga $t$ tabel untuk kesalahan $12 \%$ uji dua fihak dan $\mathrm{dk}=\mathrm{n}-$ $2=65$, maka diperoleh $\mathrm{t}$ tabel $=1,782$, ini berarti hasil perhitungan uji signifikan $t$ tes lebih besar dari dari harga $\mathrm{t}$ tabel atau $12,827>1,782$. Dengan demikian hipotesis kerja (Hi) yang berbunyi bahwa "ada hubungan antara penguasaan teori dasar-dasar elektronika dengan penguasaan pengukuran komponen elektronika dalam meningkatkan prestasi belajar pada mata pelajaran dasar kompetensi kejuruan materi memahami dasar-dasar komponen elektronika siswa kelas X SMKN 1 Geneng di terima. Hal ini dapat dimaklumi, karena bila ditinjau dari sistem evaluasi dalam ruang lingkup pada mata pelajaran dasar kompetensi kejuruan, penekanan yang diberikan pada pengembangan masuk dalam ranah kognitif dan psikotorik.

\section{Kesimpulan}

Berdasarkan pembahasan data pada bab IV maka kesimpulan dalam penelitian ini adalah rerata prosentase hubungan antara penguasaan teori dasar-dasar elektronika dengan penguasaan pengukuran komponen elektronika terhadap peningkatan prestasi belajar pada SMKN I Geneng kelas X teknik instalasi listrik.

\section{Daftar Pustaka}

Arikunto Suharsimi. 2006. Prosedur Pendidikan. Jakarta. Rineka Cipta. http://lutfi4math.wordpress.com/2012/02/2 3/evaluasi-penilaian-dan-pengukuranpembelajaran/

IKIP PGRI Madiun. 2012. Pedoman Penulisan Skripsi.

p_musa.staff.gunadarma.ac.id/Downloads/ files/8048/Komponen.pdf 
Riyanto Yatim Dr. 2001. Metodologi Penelitian Pendidikan. Surabaya

Slameto Drs. 2010. Belajar dan Faktorfaktor Yang Mempengaruhinnya. Jakarta. Rineka Cipta.

Sugiyono Prof. 2006. Metode Penelitian Kuantitatif, Kualitatif dan $R \& D$. Bandung 